\title{
A Modified Wet Chemical Oxidation-Nonaqueous Coulometric Titration for the Determination of Traces of Carbon in Metals
}

\author{
Hiroyuki KUTSUMI and Tatsuhiko TANAKA
}

\begin{abstract}
Synopsis :
When metal samples are decomposed with mixture solution of potassium dichromate and sulfuric acid, there are a lot of chances to have serious explosions because of the reaction between the hydrogen gas generated and the oxygen gas used as carrier gas. The assembly was developed for evacuating to remove the hydrogen with a vacuum pump through a palladium membrane heated at $400^{\circ} \mathrm{C}$ in order to avoid such a dangerous phenomenon. The wet chemical apparatus installed the newly developed assembly was used for the determination of traces of carbon in two kinds of high-purity iron, steels, aluminum and high-purity indium samples. Since the evolved hydrogen could be thoroughly removed from the train, the detonation was never encountered in the determination. The formed carbon dioxide was titrated coulometrically in nonaqueous medium, with a photometric end-point detection. Trace amounts of carbon $[(0.4 \sim 252 \mathrm{ppm}(\mathrm{m} / \mathrm{m})]$ in the metal samples could be determined in safety and with good precision and accuracy. The fluctuation of the blank value was little all through the experiment. The time taken to a single determination was 25 to $155 \mathrm{~min}$.
\end{abstract}

Key words : element analysis; wet chemical method; coulometric titration; carbon determination ; iron ; steel ; aluminum; indium.

\section{1. 緒言}

クロム酸㴀液による酸化に齿の゙く门典的な湿式酸化分

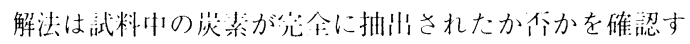
るのが行易であり，通裳の条作下では燃焼が困難または

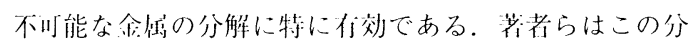

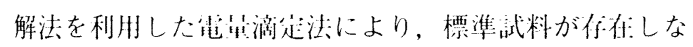

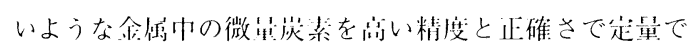
きることを明らかにしだ2. しかしこのナ法による全 属試料の分解では多水絭が発牛し，その水尗が加熱

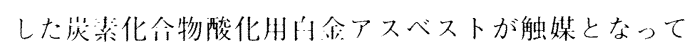

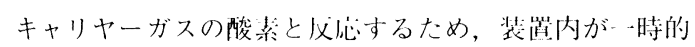
に減けとなって电解液が逆流したり，ときには㷷発を引 き起こすことがあった。特に金偊武料が微練のときには しばしば起こり，伦険なために这蝫は不川能になった。

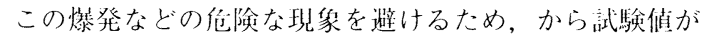
安分した後，試料分解液をいったん冷却してから金属武 料を投人し，徐々に政加熱する方法を採用したが，から 試験值が不方定になって起星できなかった。涏って，是 菓操作を安全かつ正確に行うためには水尛を分離除去す る装菅の開発や方法の败良の必荌があった。

そこで本研究では，水类を選択的に透過する性啠を们 するパラジウム膜からなる装耑を設計して導人し, 分解 時に多量に発生する水素の除上を試みた。矢際に，激し く酸化分解しやすい金咸武料の分析にこの装崖を利用し たところ，㷷発などの危険は食くなく，荌全にかつ精度 良く金属中の微星岸素を定量することができたのでそれ らの綃果を報㸝する。

惝成 3 年 3 月 6 月1 妥付 (Received Mar. 6, 1991)

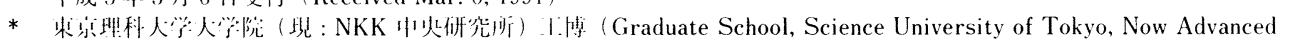
Technology Research Center, NKK Corporation)

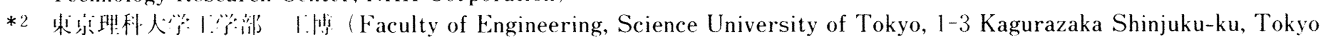
162) 


\section{2. 実 験 方 法}

\section{$2 \cdot 1$ 装置}

水素を除上するために考案した装耑を Fig. 1 に亦す。 水素透過部分は, 内栙 $3 \mathrm{~mm}$, 侧厚 $0.2 \mathrm{~mm}$, 長さ約 290 $\mathrm{mm}$ のパラジゥムU 管からなり, 約 $400^{\circ} \mathrm{C}$ に加熱し た。パラジウムとホウケイ酸ガラスの膨非係数は非常に 異なるので，パラジウムとホウケイ酸ガラスはコバール 仓食を用いて接令した。パラジウム管を透過した水紫は 油回転芷突ポンプを用いて吸引除去した。

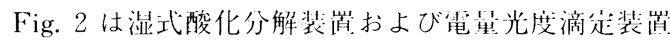
であるが，Fig. 1 の水素除上装耑を取り付けた以外は 前報2)とほぼ间じである。白食アスベス卜管は独英ガラ ス製，それ以外の部分はホウケイ酸ガラス製である。連 綃部は総すり介おせとし，分解フラスコおよび䉓望光度 滴起七ル部分を除くガラスのすり众わせ部分にはアピエ ゾングリースまたは蛍りん酸を荼った。分解フラスコお よびトラップから発牛する硫酸ミストは，汾却器の上部 とトラップのガスの川嵪く軽く詰めた石英ウールででき るたけ除上するようにした。循環式電量光度滴定セルの ガス吹这み口には，陰概液の逝流を游ぐために异を取り

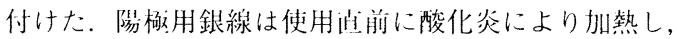

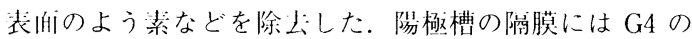
ガラスろ過板を用いた。

\section{$2 \cdot 2$ 試薬}

使用した試薬はすべて特級足で，ニクロム酸カリウム および硫酸は次のように精製して用いた。们英ガラス製

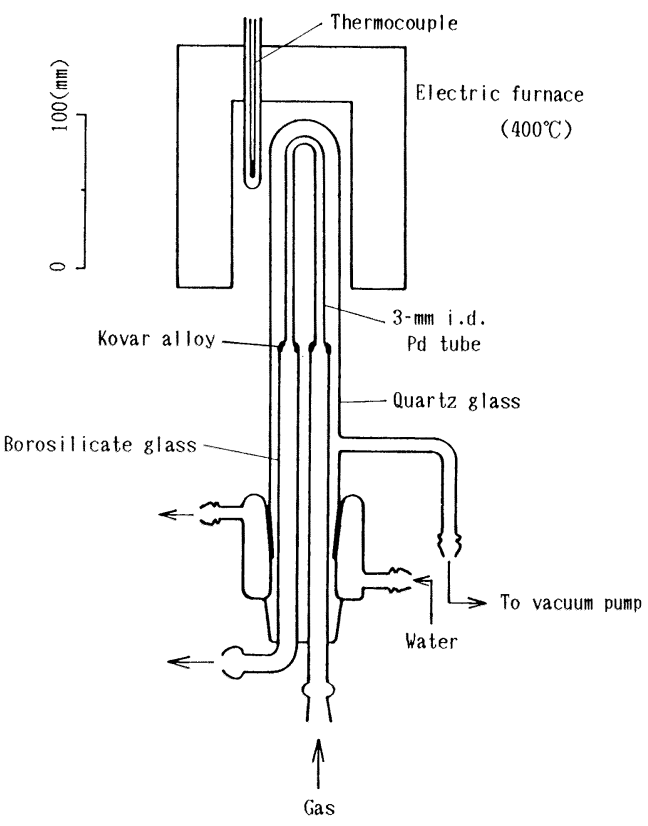

Fig. I. Assembly for removal of hydrogen.

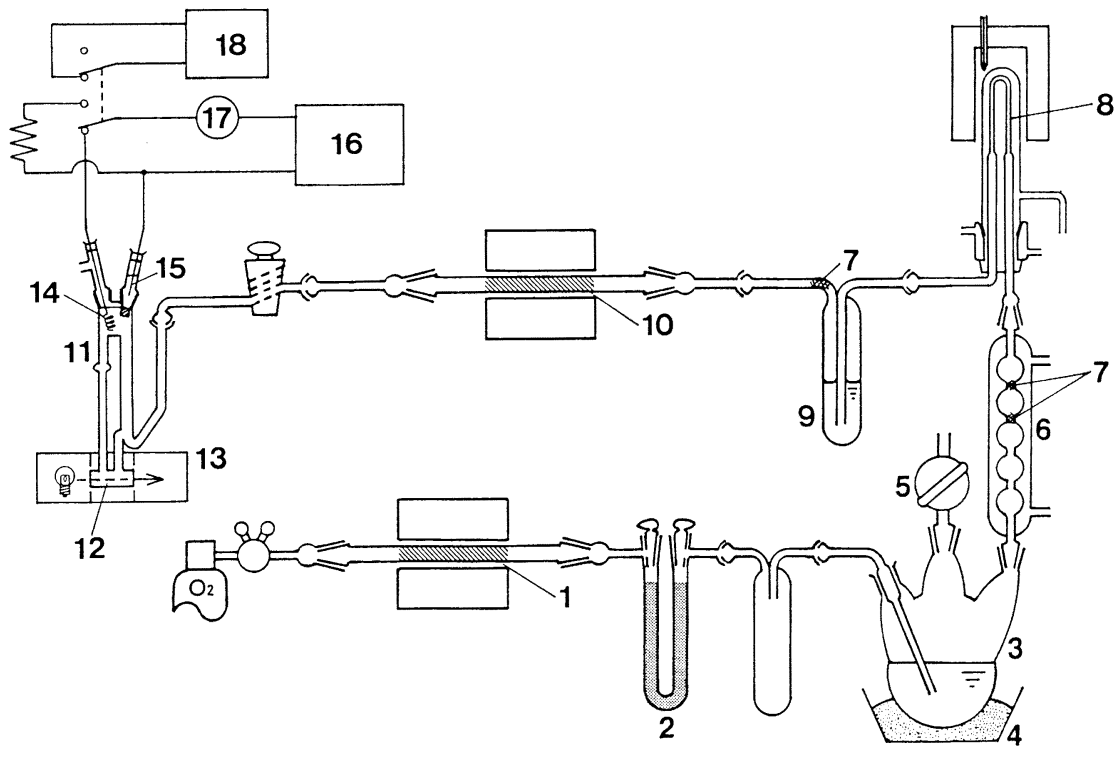

1 and 10 : Platinized asbestos $\left(800^{\circ} \mathrm{C}\right) \quad 2$ : Soda talc $\quad 3:$ Decomposition flask $\quad 4$ : Sand bath $\left(\mathrm{ca} .125^{\circ} \mathrm{C}\right)$ 5: Teflon stopcock of sample inlet 6: Condenser 7: Quartz wool 8: Pd tube 9: Trap (purified $\left.\mathrm{H}_{2} \mathrm{SO}_{4}\right)$ 11: Coulometric cell 12: Light path 13: Process colorimeter 14: Pt cathode 15: Ag anode 16: Constant current source $17: \mathrm{mA}$ meter $18:$ Timer

Fig. 2. Schematic diagram of apparatus. 
蒸発片中に取り出した二クロム酸カリウムを約 $400^{\circ} \mathrm{C}$ (融点 $\left.398^{\circ} \mathrm{C}\right) に 5 ー 6 \min$ 溶融して炭素化今物を分解し て精製し，ガラス瓶中に保伱した。硫酸は，上淤の精製 したニクロム酸カリウムを 0.5 mass\% 加えた後数時䦌 煮沸して精製した。

電解液: $0.035 \mathrm{~g} / \mathrm{ml}$ よう化カリウム, $3.5 \mathrm{vol} \% 2$-ア ミノエタノール, $3.5 \mathrm{vol} \%$ 水打よび $0.002 \mathrm{~g} / \mathrm{ml}$ チモー

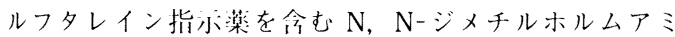
ド浴液である、隊柯槽にも间じ溶液を用いた。この浴液 は使用の都度新しく衕製した。

スクロース標準液: 市敗の水仯糖を水, エ夕ノール, ジエチルエーテルで順次洗游後，直穹デシケーター中て 減压乾燥し，メノウ乳鉢で軽く砕いてから水酸化ナトリ

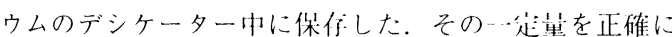
量り取り，水に溶解しメスフラスコで-..分量にうすめ, 3 日以内に使用した。

\section{$2 \cdot 3$ 定量操作}

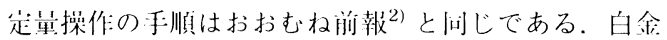
アスベスト（白食含们涪：10 mass\%）の加熱用電気炉 を $800^{\circ} \mathrm{C}$ に早㵋した後, 約 $150 \mathrm{ml} / \mathrm{min}$ の流量で酸素 キャリヤーガスを流し，一連の装莦内の召父を酸素で峘 換する. ク口ム酸・硫酸の武料分解液約 $140 \mathrm{ml}$ を分解フ ラスコに人れ，溶液中に残位する荻素化令物を除去する ために加熹沸騰する。水絭除上装瞋加熱用電気炕は $400^{\circ} \mathrm{C}$ に界㴓しておく.

次に電解液紗 $10 \mathrm{ml}$ を電虬光淓滴定セルに採り, 酸素 キャリヤーをセル巾に導人する。我解液 (陰極液)に吸 収された二酸化成素による酸を，5 mA の盗電流を用い て白全陰杨（表泊穔約 $1 \mathrm{~cm}^{2}$ ) で䉓解発牛させた塭基で

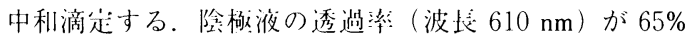
になったときに电解を倌水する。光路长は $20 \mathrm{~mm}$ であ る。 5 または $10 \mathrm{~min}$ 吸收後の笔解で消費される䉓気量,

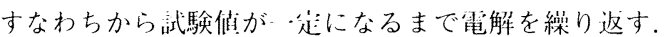

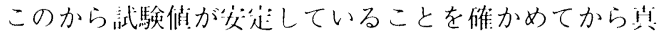
空ポンプの電源を人れ，叫り取った食的試料を試料投入 コックから武料分解液中へ投人する。抽出した二酸化炭 素を陰極液に收收した後，武料投入前のから試験值にな

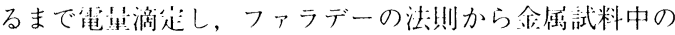

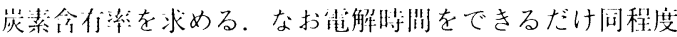
にするため，採彼した苂少鞓に忍じて，電解には 0.2 から $5 \mathrm{~mA}$ の起䀝流を用いる。

\section{3. 結果と考察}

\section{$3 \cdot 1$ 試料分解液の検討}

金属武料を少食に分解するために，金属の種類に心し
て試料分解液組成を変える必要がある。ニクロム酸塩と 硫酸の混合物が武料分解液として一般に用いられる. Chandramoula らは，硫酸への溶解度が二クロム酸カリウ ムよりも大きい二クロム酸ナトリウムの使用を推奨して いる3)。しかしニクロム酸カリウムのほうが精製が行易 で純乔が得られやすい。著者らは $0.2 \mathrm{~mol} / 1$ 二クロム酸 カリウムと 5 〜 $8 \mathrm{~mol} / \mathrm{l}$ 硫酸からなる试料分解液を使用 して，金属試料中の荻素を走量的に酸化抽出できること を確㴓した2).そこで本研究でもニクロム酸カリウムを

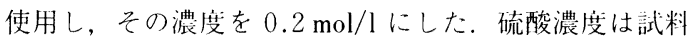
によって変え，スクロースとアルミニウムでは $6 \mathrm{~mol} / \mathrm{l}$, 鉄鋼では $5 \mathrm{~mol} / \mathrm{l}$ ，インジウムでは $8 \mathrm{~mol} / \mathrm{l}$ を使用した。 アルミニウムおよびインジウム試料では分解を速めるた めに，試料分解液に硫酸釦（II）五水利物 10１6 mg を 添加した.

\section{$3 \cdot 2$ から試験値の評価}

微量成分分析において信頼できる絬果を得るためには から試験值を小さくすることが重要となるので，から試 験值の低減化を試みた。本法に打ける $10 \mathrm{~min}$ 当たりの から試験值は $0.3 \sim 0.5 \mu \mathrm{g}$ であり，酸素父流中での直接 高温燃焼法でのから試験值 $(0.4 \sim 0.6 \mu \mathrm{g} / 10 \mathrm{~min})^{4) 5)}$ と ほぼ间程度であった。市貶の酸素[約 $22 \mu \mathrm{gC} / 10 \mathrm{~min}$ (酸素 $1 \mathrm{ml}$ 当たり $0.015 \mu \mathrm{g}$ の荻素を含む)]を加熱した 白金アスベストとソーダタルクを通して精製した後の荻 素量は $0.05 \mu \mathrm{g} / 10 \mathrm{~min}$ まで減少し，分解フラスコ中に 試料分解液を人れないときの $10 \mathrm{~min}$ 当たりのから試験 值が $0.2 \mu \mathrm{g}$ 前後であることから，から試験值の大部分 は試料分解液から生じていることは明らかである。そこ で試料分解液の調製に使用した試薬類を史にいろいろな オ法で精製してみたが，これ以たから狱験値を低減させ ることはできなかった，是量前後のから試験値の安足性 は極めて艮好で, から試験值の日䦌変動もほとんどなく， 微量荻素の正確な分望が川能であった。なお，一度加熟 沸騰した試料分解液を空温まで泠却した状態で測定した 埸令のから試験倠は $0.3 \mu \mathrm{g}$ 前後であった。

分解フラスコ中に試料分解液を導人後，その武料分解 液を加熱沸騰することによりから試験値を速く茇远させ ることができた。しかし，煮沸をむやみに产く続けても から武験值の減少は㪊められず，かえって酸化分解能力 の低下のために試料の分解が不川能となった。缒って， 武料投人前の試料分解液の煮沸時洲は 3 - $4 \mathrm{~h}$ とした。

\section{$3 \cdot 3$ スクロース中の炭素の定量結果}

本法の正確さを確認するために，スクロース標潐液中 の炭素を起星した，標準液の一走量 $(50 \mu \mathrm{l})$ をマイクロ シリンジで採取し，試料投人コックを外して取り付けた 
Table 1. Determination of carbon in sucrose.

\begin{tabular}{|c|c|c|c|c|c|}
\hline \multirow{2}{*}{$\begin{array}{c}\text { Carbon } \\
\text { taken } \\
(\mu \mathrm{g})\end{array}$} & \multirow{2}{*}{$\begin{array}{c}\text { No. of } \\
\text { determinations }\end{array}$} & \multicolumn{2}{|c|}{ Carbon found ( $\mu \mathrm{g}$ ) } & \multicolumn{2}{|c|}{ Blank value $(\mu \mathrm{g})$} \\
\hline & & Mean & $\mathrm{SD}^{\mathrm{a}}$ & Mean ${ }^{b}$ & $\mathrm{SD}^{\mathrm{a}}$ \\
\hline 2.36 & 2 & 2.30 & 0.13 & 0.31 & 0 \\
\hline 1.56 & 3 & 1.52 & 0.01 & 0.41 & 0 \\
\hline 0.75 & 3 & 0.72 & 0.01 & 0.61 & 0 \\
\hline 0.28 & 5 & 0.28 & 0.01 & 0.48 & 0.04 \\
\hline 0.12 & 4 & 0.12 & 0.01 & 0.50 & 0.05 \\
\hline 0.08 & 2 & 0.08 & 0.01 & 0.29 & 0 \\
\hline 0.04 & 4 & 0.04 & 0 & 0.36 & 0.01 \\
\hline $0.032^{\mathrm{c}}$ & 3 & 0.031 & 0.002 & 0.588 & 0 \\
\hline $0.014^{c}$ & 3 & 0.015 & 0.002 & 0.411 & 0 \\
\hline
\end{tabular}

セプタムを通して㨁接分解フラスコ内に注人した。得ら れた結果を Table 1 に示す。相対標準偏差 $13 \%$ 以内で $0.015 \mu \mathrm{g}$ までの岸素が筀量できた。これらの結果は， 水素除之装置を取り付けた場介でも高い精度と正確さで 微量炭素が足量できることを示している。1 試料の分析 所要時䦌は 10〜30 min であった。

キャリヤーガスの酸素が酸化分解時に発生した水䋕と 必忍するのであるから，酸素を不活性ガスに狊き換え れば樭発などの危険を避けることができるはずである． そこで酸素の代わりにキャリヤーガスに究素を用いた。 この場介には，Fig. 2 中の二つの白金アスベストを $750^{\circ} \mathrm{C}$ に加熱した酸化銅（II）に取り替え，水素除上装 耑は取り外した。このうj法により，スクロース標準液中 の $0.06 \mu \mathrm{g}$ 以.上の岸素が相対標準偏差 $11 \%$ 以内で正碓 に足量でき，䈐素の抽出は完全であることが確かめられ た。ただし，先の水素除上装置を用いた結果（Table 1) に比べ定量下限は高く，また終点検出感度はいくらか鈍 いので, 長光路 $(30 \mathrm{~mm})$ の電量光度滴定セルを使用す る必要があった。1 試料の分析所要時㨽は 10 45 minで あった

\section{$3 \cdot 4$ 金属中の炭素の定量結果}

燃焼が相難で，前報2)において㷷発しやすかった金禹 试料などに本法を他用した。一般に金属就料表而はかな

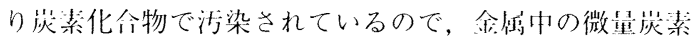
を正確に起量するためには試料表泊字酸洗浄する必要が ある6)。そこで，高純度鉄 B 抢よびアルミニウム( 純 度表示值：99.5\%）は希硝酸で洗源し，水，ア七トンま たはメタノール，次いでイ油ベンジンで超沙波洗浮後，

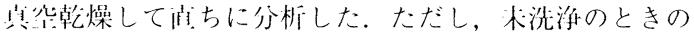

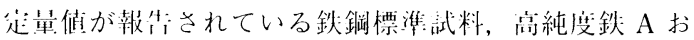
よび高純度インジウム（純度表示傎：99.999\%）につい ては比挍のために全く洗游せずに分析に供した、インジ ウムの形状は粒状，そのほかは划㲂状である。絒かい食 伯武料の場价はパイレックスガラス滗の・端を封じたカ

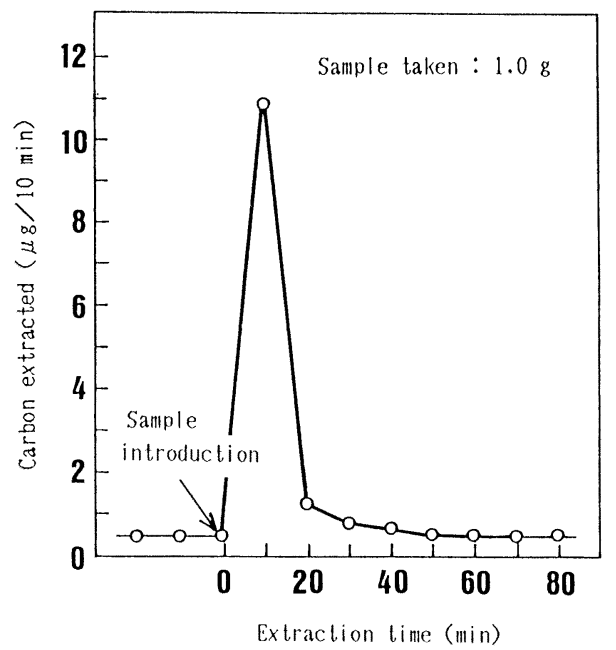

Fig. 3. Typical extraction curve of carbon in high-purity iron B (drillings).

プセル（内径 $7 \mathrm{~mm}$, 垃さ $16 \mathrm{~mm}$ ) 中に虬り彼り, 分解 フラスコ内にカプセルごと投人した。な抽，このときは 定量操作の妵後にガラスカプセルのみを投人し，カプセ ルから坐ずるから试験佃を求めて補正したた

Fig. 3 は抽出曲線の一例（陚料：的純度鉄 B) である が，いずれの試料に㧊いても分解フラスコに試料投人後

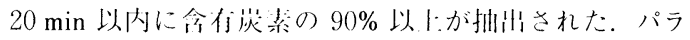
ジウム管の加熱温度は川能な煺り占いほうがよいが,

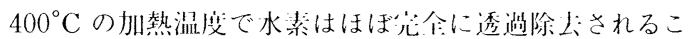
とが分かった。すなわち，此料分解時に発非する水素を 除去しないときには岸素化价物酸化朋白食アスベストの 後部の低㴓部分に必ず観祭された人望の水滴は, $400^{\circ} \mathrm{C}$ に加熱したパラジゥム管を叹り们けた場介には全く生じ なかった。また，武料投人後の訟化分解は水采除上装置

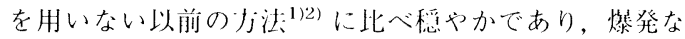
どの伦険は全く起こらなかった。

得られた告星綃果を Table 2 に亦寸。インジウムを

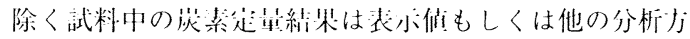
法によって得られた佔と非常に发く・呚している。また

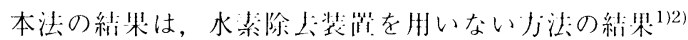

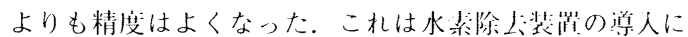
よって試料投入前後のから武駼㑤の父定性が增したこと

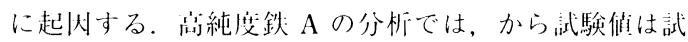

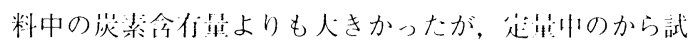

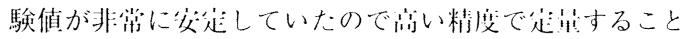
ができた。また本法により得ら机た佔は，助燃剤にすず

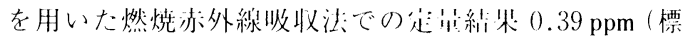


Table 2. Determination of carbon in various metals.

\begin{tabular}{|c|c|c|c|c|c|c|}
\hline \multirow{2}{*}{ Sample } & \multirow{2}{*}{$\begin{array}{l}\text { Sample taken } \\
(\mathrm{g})\end{array}$} & \multirow{2}{*}{$\begin{array}{c}\text { No. of } \\
\text { determinations }\end{array}$} & \multicolumn{3}{|c|}{ Carbon found } & \multirow{2}{*}{ 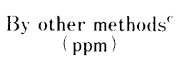 } \\
\hline & & & Mean (ppm) & $\mathrm{SD}^{\mathrm{a}}(\mathrm{ppm})$ & $\operatorname{RSD}^{\mathrm{h}}(\%)$ & \\
\hline \multirow{3}{*}{$\begin{array}{l}\text { Standard steel }\left\{\begin{array}{l}\operatorname{JSS} 200-4^{d} \\
\operatorname{BAM} 043-1^{\circ}\end{array}\right. \\
\text { High-purity iron }\left\{\begin{array}{l}A \\
B\end{array}\right.\end{array}$} & $\begin{array}{c}0.08 \sim 0.11 \\
0.1 \sim 0.3\end{array}$ & 5 & 78.9 & 1.1 & 1.4 & \multirow{5}{*}{$\begin{array}{l}0.39[0.09]^{\mathrm{r}} \\
10.2\left[0.2^{5)} \cdot 1.9^{6)}\right] \\
11.1[0.4]^{1)} \\
250[4.8]^{1)} \\
0.83[0.05]^{21}\end{array}$} \\
\hline & 0.4 & 3 & 0.42 & 0.01 & $\begin{array}{l}8.1 \\
2.8\end{array}$ & \\
\hline & $0.5-1.0$ & 3 & 11.3 & 0.2 & 1.8 & \\
\hline Aluminum (2N5) & $0.1 \sim 0.2$ & 3 & 252 & 0.4 & 0.2 & \\
\hline High-purity indium $(b N)$ & $1.1-1.3$ & 3 & 3.32 & 0.05 & 1.5 & \\
\hline \multicolumn{7}{|c|}{$\begin{array}{l}\text { a : Standard deviation } \\
\mathrm{b}: \text { Relative standard deviation } \\
\mathrm{c}: \text { Values in square brackets indicate standard deviations in ppm }(3-10 \text { determinations) } \\
\text { d: The Iron and Steel Institute of Japan (certified value } 0.008 \%) \\
\text { e: Bundesanstalt für Materialprüfung (certified value } 0.0014 \% \text { ) } \\
\mathrm{f}: \text { Value obtained by combustion infrared absorption spectrometry }\end{array}$} \\
\hline
\end{tabular}

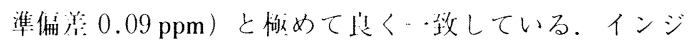

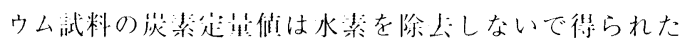

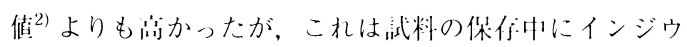

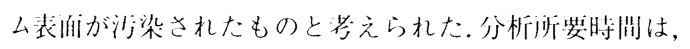

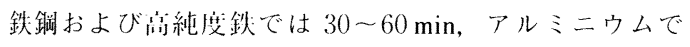
は 110 155 min, インジウムでは 25－45 min であった。

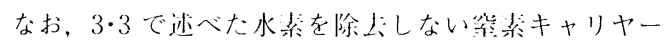

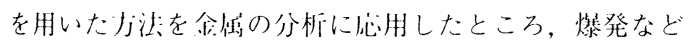
の危険な现禹は起こらなかったが, 金属试料分解時の酸 化不足のためか満起な起早絬果は得られなかった。

\section{4. 結言}

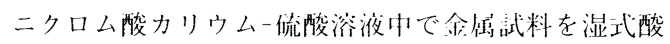
化分解する際に発牛すする水菜による㷷発を四避するた め，装崌などの收鼓を武みた。その紏果，

1 )水絭の分解除上には， $400{ }^{\circ} \mathrm{C}$ に加熱したパラジウ ム管を分解フラスコに続く造流冷却器の上部に取り付 け，無帘ポンプで外僛から吸引す机ばよいことが分かっ た.

2 )この水尖除上桜管を用いることにより，から試験

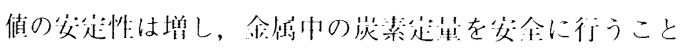

ができた。

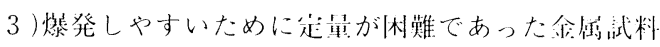

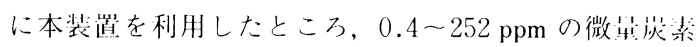
を高い精度と正確さで这诔できた。

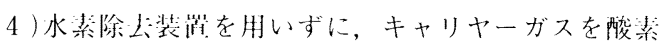
から学素に代えるだけでも㷷発の伦険を避けることはで きたが，金属武料では渾是な分析維果が得ら机なかった。

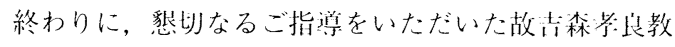
授並びに实験に協力された新明秀音(現：シャープ(株)) 仿に深謝いたします。

\section{文献}

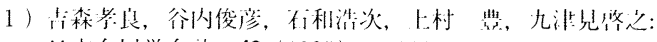
H本金禹学:公比, 49 (1985), p. 144

2) H. Kutsumi, T. Yoshimoki and T. Tanaka: Anal. Sci., 5 (1989), p. 95

3 ) V. Chandramouli, $R$. B. Yadav and P. R. Vasudeva Rao: Talanta, 34 (1987), p. 807

4) 古森考良, 行内俊颜: 分析化学: 32 (1983), p. 547

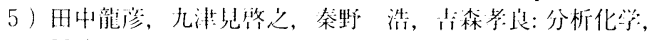
38 (1989), p. T45

6）古㷊考良，行内俊彦：分析化学: 32 (1983), p. 110 